\title{
SOCIALIZATION AND TRAINING ON IMPLEMENTATION OF INVESTMENT SELECTION STRATEGIES
}

\author{
Hakiman Thamrin \\ Universitas Mercu Buana Jakarta, Indonesia.
}

\begin{abstract}
There are only $29.66 \%$ of Indonesia population who really understand and know about financial products and services. From this number, those who truly understand the capital market are only $4.4 \%$ and those who invest in the new capital market are around $0.4 \%$. That number is very low if we compare to neighboring countries, for example in Malaysia, the population participating invested in capital market has reached 3.8 million or $12.8 \%$. While in Singapore 1.5 million or 30\% of the population has invested in stock market and in China 100.4 million or $13.7 \%$ of the population has invested in the stock market. There are only small number of people who invested in the Indonesia stock Exchange, it means there is a big potential to increase the number of investors in IDX. All parties, not only governments and IDX must conribute to encourage people to invest in the capital market. Therefore, the community needs to be given knowledge about what types of investments can be chosen, especially those on the IDX, how to invest, how to assess the performance of the investment, and the risks that may arise.
\end{abstract}

Keywords: Investment; Capital Market; Community.

\section{INTRODUCTION}

\section{Background}

The Financial Services Authority (OJK) claims that not every Indonesia's population knows about financial industry. It is evidenced that only $29.66 \%$ of Indonesia's 250 million people who know about financial facilities. OJK also claims the number of investors in the capital market annually has always increased.

Director of Investment Management of Capital Market, Financial Services Authority Sujanto said, "There are currently $29.66 \%$ of Indonesia population who understand and know financial products and services. From those numbers that really understand the capital market is only $4.4 \%$ and who invest in the new capital market about $0.4 \%$. " He said when encountered in the event of Indonesia Investment Festival 2017 in Kelapa Gading Mall, Jakarta, Friday (27/10/2017).

That number is very low if we compare to neighboring countries, for example in Malaysia, the population participating invested in capital market has reached 3.8 million or $12.8 \%$. While in Singapore 1.5 million or $30 \%$ of the population has invested in stock market and in China 100.4 million or $13.7 \%$ of the population has invested in the stock market.

Actually, the potential of Indonesia's population to invest in capital markets is huge. Because, as much as 174 million people or $67 \%$ of Indonesia's population is in a productive age. There are only small number of people who invested in the Indonesia stock Exchange, it means there is a big potential to increase the number of investors in IDX. All parties, not only governments and IDX must continue to encourage people to invest in the capital market.

South Meruya Village, located in West Jakarta with a population of 23,861 people spread over 9 RWs and 114 RTs, most people are still unfamiliar with the financial industry, especially how to invest in the financial sector through the Indonesia Stock Exchange. Therefore, Mercu Buana University through its Community Service Program "Socialization and Training on Implementation of Investment Selection Strategies in South Meruya Village".

\section{Problem Identification}

South Meruya Village with an area of 486 ha which is divided into 9 RWs and 114 RTs with a population of 23,861. However there are problems that can be identified as follows:

1. Lack of community knowledge about the financial industry in Indonesia.

2. Lack of community knowledge about existing financial facilities.

3. Lack of ability / reference owned by the community about the capital market.

4. Lack of ability / reference about how much return can be obtained from the capital market if someone invest in capital market.

5. Lack of information that investing in the Indonesia Stock Exchange does not require large funds. 


\section{TARGET AND OUTCOME}

\section{Target}

The general target that is to be achieved through this activity is to improve the knowledge and ability of the community in South Meruya village West Jakarta on investment forms, especially the investments that exist in the Indonesia Stock Exchange.

Spesific target to be achieved are:

a. Increase the number of people who understand about investing in the capital market properly and correctly.

b. With this educational program the community can understand what the capital market is and what the capital market is like and how to conduct transactions in the capital market.

c. With this educational program can remove the perspective of the investment in the capital market that requires large funds and very expensive.

\section{Outcome}

The outcomes are as follows:

1. Increasing community knowledge about how to choose investments.

2. The eagerness to invest.

3. The outcome of this training are more and more people who invest in stock investments in the Indonesia stock Exchange.

Table 1. Outcome Target Plan

\begin{tabular}{lll}
\hline No & Types of Outcome & $\begin{array}{l}\text { Performance } \\
\text { Indicator }\end{array}$ \\
\hline 1 & Scientific publications in journals/proceedings & No \\
\hline 2 & Publications in mass media (print / electronic) & No \\
\hline 3 & Increased the turnover of the partner engaged in the economic field & No \\
\hline 4 & Increased the quantity and quality of products & No \\
\hline 5 & Increased understanding and community skills & Yes \\
\hline 6 & Increased tranquility/Public health (general community partners) & No \\
\hline 7 & Services, models, social engineering, systems, products/goods & No \\
\hline 8 & Intellectual property rights (patents, simple patents, copyrights, trademarks) & No \\
\hline 9 & Teaching materials & No \\
\hline
\end{tabular}

\section{IMPLEMENTATION METHOD}

\section{Implementation of Activity}

This activity has been implemented on:

Day/date $\quad: \quad$ Friday, $5^{\text {th }}$ July 2019

Time $\quad: \quad 08.00-12.00$ WIB

Place $\quad$ : $\quad$ South Meruya village, West Jakarta.

\section{Target}

Target groups who get the socialization material is the community in Meruya Selatan village, West Jakarta. The number of participants invited as many as 30 people consisting of communities in various RT and various RW in South Meruya village, West Jakarta.

\section{Method of Activity}

The methods of activity that used are as follows:

1. Structured, in the form of material exposure to provide knowledge and understanding of the types of investments through theoretical exposure.

2. Explanation about Indonesia Stock Exchange

3. Simulation of making investment planning for all participants. 


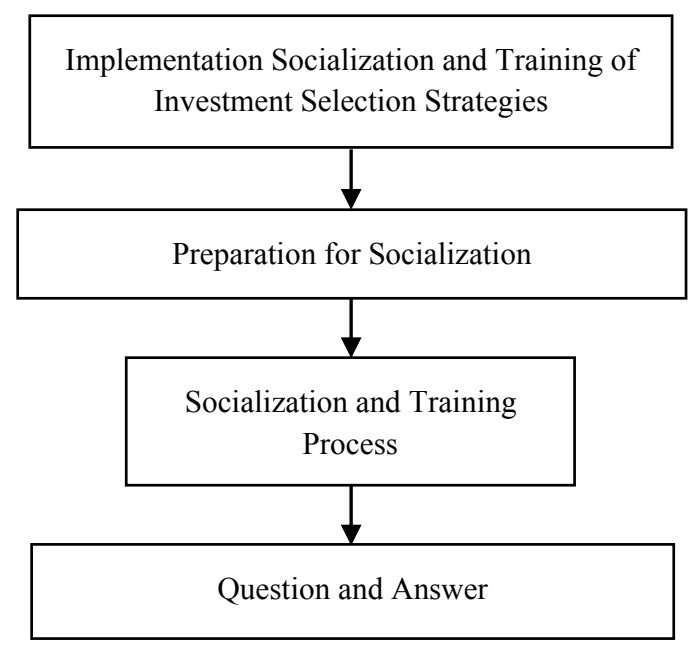

Figure 1. Method of Activity

\section{Outcome Types Based on Activity Plan}

1. It is expected that with the "Socialization and Training on Implementation of Investment Selection Strategies in South Meruya village", it will increase the knowledge of the surrounding community on how to choose investments.

2. Then the eagerness to make an investment will arise.

3. Furthermore, more and more people will invest, especially investing in stock on the Indonesia Stock Exchange.

\section{RESULT AND DISCUSSION}

\section{Result}

Socialization and Training on Implementation of Investment Selection Strategies in Meruya Selatan village, West Jakarta, was attended by the community in Meruya Selatan Village, West Jakarta. The number of participants invited was 30 people consisting of people in various RTs in various RWs in Meruya Selatan Village, West Jakarta. Participants in the socialization and training were attended by 25 people from South Meruya village.

Table 2. Rundown of Activity

\begin{tabular}{rlll}
\hline NO & TIME & TOPIC & EXECUTOR \\
\hline 1 & $08.00-08.30$ & Registration & Committee \\
\hline 2 & $08.30-10.30$ & Socialization & \\
\hline 3 & $10.30-12.00$ & Coconut-entrepreneurial Case study & \\
\hline
\end{tabular}

In accordance with socialization and training methods, during the activities after the presentation, question and answer session was opened. In this session the participants asked about how to choose a good investment. The point is investments that will produce optimal returns.

Here the speaker emphasized that every investment activity will contain risks. This must be realized by those who will invest, and in financial theory it is known that the higher the estimated return, the higher the risk that may be received.

Then the participants were also given information about the LQ-45 index, which is 45 shares that were classified as the "blue chip" group. If the investor owns the LQ-45 stock, then their stock belong to the group of stock that are liquidated on the Stock Exchange, and will usually give results that are in line with the Exchange index. For example, if the index rises, then the share price will go up, and vice versa. 


\section{Discussion}

From the "Socialization and Training on Implementation of Investment Selection Strategies in Meruya Selatan, West Jakarta", it is seen that the community in this village is generally still lacking in knowledge about the stock market. Even though they live in Jakarta where the Capital Market, and Indonesia Stock Exchange, are located, information about what is the IDX has not yet reached them.

With this community service activities carried out by Mercu Buana University, the information gained by the community regarding investment selection strategies has increased.

\section{CONCLUSION AND SUGGESTION}

\section{Conclusion}

From the Community Service activities conducted by lecturer and students at Mercu Buana University in Meruya Selatan Village, West Jakarta, we can conclude that:

a. Is true that there are still many Indonesian population, especially those in South Meruya village who are not familiar with the Indonesia Stock Exchange.

b. Low ability of the community to choose alternative investment especially in financial sector

c. The community does not know how to invest in the Indonesia Stock Exchange

\section{Suggestion}

a. More socialization should be done to the community about alternative to invest

b. Need to open opportunities to general public to consult about the oppoortunity to invest

\section{REFERENCES}

Fisher, I, The Theory of Interest, New York, Macmillan, 1930

Husnan . S, " Corporate Spending, Fundamentals of Financial Management ", Liberty Yogyakarta, 1989.

, " Fundamentals of Portfolio Theory ", Liberty Yogyakarta, 1989.

Riyanto . B, " Fundamentals of Corporate Expenditures ", BPFE Yogyakarta, 1989. 


\title{
VERTICAL GARDEN UTILIZATION TRAINING FOR HIGH SCHOOL / STUDENTS IN JAKARTA
}

\author{
Inggit Musdinar Sayekti Sihing, Sri Kurniasih, Dody Kurniawan \\ Universitas Budi Luhur, Indonesia.
}

\begin{abstract}
The existence of open spaces in private urban villages in Jakarta is very rare. Occupancy at the center of the city causes people choose land for buildings rather than open space. Even though Jakarta has ranked in the top 5 countries with an upper threshold. Vertical garden was chosen as an alternative greening solution on limited open space. Vertical garden assistance and training is aimed at students from PGRI 15 High School located around the campus of Budi Luhur University, South Jakarta. Students are introduced to the importance of greening for environmental health and are encouraged to be creative in creating vertical garden forms with a variety of ideas. The approach method used is tri-daya, i.e. i) social power, ii) environmental power, and iii) economic power. The concept of Social Power is to invite students to become individuals who are more concerned about the environment capable of providing solutions to the completion of greening in urban areas that are increasingly limited. The concept of Environmental Power aims to invite students to take part in a residential or school environment to implement a vertical garden and increase their creativity in developing various vertical garden designs. And the concept of Economic Power is the result of the production of making vertical gardens can be used for themselves or sold to the general public, which in turn can increase the economic value of the surrounding community.
\end{abstract}

Keyword: Open Space, Vertical Garden, High School Students

\section{INTRODUCTION}

The growth of the city of Jakarta is very rapid and the decreasing amount of land in the urban villages, it is necessary to have an activity that can contribute to greening in limited land. It also builds and develops their talents and abilities towards increasing insight and creativity, so that the idea of the "Vertical Garden Utilization Training for High School Students in Jakarta" can be equipped to expand their horizons in order to prepare themselves to continue the level of higher education or the world of work that requires skills to reach a bright future. Besides that, the main objective of this training activity is to explore and enhance students' creativity in the school.

\section{Cases}

Increasingly narrow urban land reduces the presence of green open space as the lungs of the city. Even at the closest level, the dwelling house, it is rare to consider how to leave land for reforestation. Land is more maximized to answer the need for space. Therefore the purpose of this activity is: how to bring greening to a residential environment with limited land?

\section{OVERVIEW OF TARGETS}

The Vertical Garden Utilization Training is intended for state / senior high school students in South Jakarta. Precisely those who are currently in class X, XI and XII. The state high school / equivalent level that was targeted in this activity was the public high school / equivalent level around Budi Luhur University. The state high school / equivalent high school targeted for this activity are:

School Name : SMK PGRI 15 Jakarta

Address : Jalan Muchtar Raya Gg. H. Doel Rt 005 / 01jakarta Selatan, Special Region The capital of Jakarta 12260

Telephone : :(021) 58904487 